\title{
Challenges and Roles of Official Statistics in the Covid-19 Pandemic
}

\section{Tantangan dan Peran Official Statistics Dalam Masa Pandemi Covid-19}

\author{
Firman*
}

\begin{abstract}
Official Statistics is a statistical activity carried out by the government relating to the collecting, processing and presenting of data in the government sector. During the Covid-19 pandemic, the government statistical activities underwent a change. Especially in the case of data collection in the field. Data collection by face to face directly begin to switch to online methods. With intertnet connection and technology information tools, activity related collecting data stiil done by online, especially to eradicate pandemic Covid-19. Official Statistics plays an important role through data produced associate with Covid-19 and with these data, the appropiate decision to accomplish pandemic Covid-19 can be made.
\end{abstract}

Keywords: Official Statistics, Collecting Data, Covid-19 Pandemic

\begin{abstract}
Abstrak
Official Statistics merupakan kegiatan statistik yang dilakukan pemerintah berkaitan dengan pengumpulan, pengolahan, dan penyajian data di bidang pemerintahan. Di masa pandemi Covid-19 ini kegiatan statistik pemerintahan mengalami perubahan. Terutama dalam hal pengumpulan data di lapangan. Pengumpulan data dengan cara bertatap muka secara langsung mulai beralih menjadi metode online. Dengan bantuan jaringan internet dan perangkat teknologi informasi, kegiatan pengumpulan data tetap dapat dilakukan secara online, terutama dalam rangka penanggulangan wabah Covid-19. Official Statistics berperan penting melalui data yang dihasilkan berkenaan dengan Covid-19 dan dengan data tersebut dapat diambil kebijakan yang sesuai untuk menyelesaikan pandemi Covid-19.
\end{abstract}

Kata Kunci: Official Statistics, Pandemi Covid-19, Pengumpulan Data

\section{PENDAHULUAN}

Official Statistics mempunyai peran yang sangat penting dalam pemerintahan. Data-data statistik yang lengkap dan akurat yang dihasilkan melalui kegiatan Official Statistics sangat berguna dalam merencanakan pembangunan dan pengambilan keputusan dalam pemerintahan. Pelaksanaan kegiatan Official Statistics melibatkan seluruh instansi/lembaga pemerintah sesuai dengan bidang tugasnya masing-masing. Data statistik dan fakta berdasarkan bukti empiris memegang peranan penting dalam kebijakan yang diambil pemerintah.

Di masa pandemi Covid-19 sekarang ini, penerapan statistik dalam pemerintahan juga mengalami penyesuaian sejalan dengan perkembangan virus itu sendiri. Setiap kejadian yang

* Kementerian Agama Kantor Wilayah Provinsi Riau, Email: firman.musra@gmail.com 
berkaitan dengan Covid-19 dan akibat atau dampak yang berhubungan dengannya selalu menjadi objek untuk pencatatan yang dilakukan oleh instansi pemerintah terkait, dalam hal ini Kementerian Kesehatan, dan Gugus Tugas Percepatan Penanggulan Wabah Covid-19. Adanya ketidakpastian kapan pandemi Covid-19 ini akan berakhir juga menjadi tantangan tersendiri bagi Official Statistics untuk ambil bagian dalam usaha menekan penyebaran Covid-19 di Indonesia.

\section{TINJAUAN PUSTAKA}

\subsection{Pengertian Official Statistics}

Mengingat pentingnya data, dalam pemerintahan dikenal istilah Official Statistics. Official Statistics (Statistik Resmi, atau Statistik Pemerintahan) adalah data Statistik yang dikumpulkan, dihasilkan, dan disebarkan oleh lembaga/instansi pemerintah (Encyclopedia.com). Data yang dihasilkan bisa berupa data sosial kependudukan, data demografi, data ekonomi, data keagamaan, data kesehatan, dan data lainnya. Menurut Undang-undang nomor 16 Tahun 1997 tentang Statistik, pengumpulan data yang dilakukan sangat berkaitan dengan tugas dan fungsi dari setiap instansi dan lembaga pemerintah yang ada, yang disebut dengan statistik sektoral. Sebagai contoh, untuk data di sektor keagamaan tentu sangat berkaitan erat dengan Kementerian Agama, data sektor kesehatan sangat berkaitan erat dengan Kementerian Kesehatan, data jumlah bencana yang terjadi dalam satu tahun berkaitan dengan Badan Nasional Penanggulangan Bencana (BNPB), dan seterusnya. Sedangkan Badan Pusat Statistik (BPS) menghasilkan data statistik dasar, yaitu statistik yang pemanfaatannya ditujukan untuk keperluan yang bersifat luas, baik pemerintah maupun masyarakat, yang memiliki ciri-ciri lintas sektoral, berskala nasional maupun regional, makro, contohnya data jumlah penduduk, data kemiskinan, data inflasi, dan lain sebagainya.

Official Statistics yang dilakukan oleh pemerintah harus memenuhi klasifikasi dan metodologi yang ditetapkan secara internasional, memenuhi prinsip ketidakberpihakan, dapat dihandalkan, relevan, hemat biaya, kerahasiaan, dan kejelasan (Statistics Estonia, 2013). Dengan memenuhi kaidah-kaidah tersebut, data-data pemerintahan sebagai produk/hasil dari kegiatan Official Statistics dapat dipakai menjadi sumber data yang baik dan diakui secara internasional.

\subsection{BAGAIMANA OFFICIAL STATISTICS DIHASILKAN}

Pengumpulan data statistik menurut Undang-undang nomor 16 Tahun 1997 tentang Statistik berlangsung melalui beberapa kegiatan. Data statistik bisa didapat melalui kegiatan sensus, survei, kompilasi produk administrasi dan cara lainnya. Dalam pelaksanaan Official Statistics dilakukan melalui tahapan-tahapan berikut, yaitu: pengumpulan data, pengolahan data, analisis data, disseminasi data, dan informasi (Ljones Olav, 2020). Pada tahapan pengumpulan data, Official Statistics sering menggunakan metode pencatatan administratif, contohnya registrasi data penduduk dalam pembuatan kartu identitas penduduk.

\section{METODOLOGI}




\section{Firman}

Paper ini merupakan paper ulasan yang menyampaikan ide / gagasan dari penulis mengenai Official Statistics. Hal yang menjadi fokus bahasan dalam paper adalah bagaimana perubahan yang terjadi dari Official Statistics yang diakibatkan oleh pandemi Covid-19 terutama pada tahapan pengumpulan data yang menjadi bagian penting dari suatu proses dalam Official Statistics.

\section{HASIL DAN PEMBAHASAN}

\subsection{OFFICIAL STATISTICS PADA KEMENTERIAN/LEMBAGA SEBELUM PANDEMI COVID-19}

Kegiatan pengumpulan data yang menjadi bagian dari Official Statistics sebelum pandemi Covid-19, dilakukan secara tradisional, bertatap muka langsung turun ke lapangan ke responden yang menjadi sumber data. Membuat form data atau daftar isian pertanyaan yang disampaikan langsung ke responden melalui survei dan wawancara adalah hal yang lazim dilakukan oleh pengelola data atau Statistisi dalam mengumpulkan data di pemerintahan. Kegiatan perjalanan dinas dalam rangka pengumpulan data, dan kegiatan orientasi, sinkronisasi dan updating data dengan mengumpulkan orang di hotel atau tempat pertemuan adalah bentuk lain yang sering dilakukan dalam mendapatkan data di instansi pemerintah sebelum pandemic Covid-19 terjadi. Keuntungan yang didapat dengan mengambil data secara langsung ke lapangan dengan bertatap muka dengan responden adalah pengelola data atau Statistisi dapat menangkap secara langsung kondisi yang terjadi di lapangan dari responden mengenai data yang akan diambil dan dikumpulkan. Komunikasi yang dilakukan dengan bertatap muka mampu untuk menggali lebih dalam mengenai permasalahan dalam pengumpulan data yang sedang berlangsung. Sementara itu kelemahan dalam pengumpulan data secara langsung adalah waktu dan biaya yang dibutuhkan menjadi lebih mahal dan waktu yang lebih lama.

Official Statistics yang dilakukan pemerintah sebelum Covid-19 merupakan kegiatan rutin tahunan yang sudah diagendakan dan terdapat di dalam Rencana Kerja Anggaran (RKA) satu tahun di setiap instansi/lembaga pemerintah. Pengumpulan data untuk publikasi data sektoral merupakan contoh publikasi rutin tahunan yang dilakukan instansi pemerintah sebelum masa pandemi Covid-19. "Buku Statistik Tahunan" merupakan contoh output yang dihasilkan di setiap Kementerian/Lembaga setiap tahunnya. Buku ini berisikan data dan informasi statistik sektoral yang ada di setiap instansi pemerintah selama satu tahun berjalan. Selain kegiatan rutin tahunan, kegiatan Official Statistics juga digunakan untuk tujuan tertentu dan waktu tertentu (accidental) oleh pemerintah, seperti pendataan masyarakat miskin untuk program Bantuan Langsung Tunai (BLT) sebagai kompensasi kenaikan harga bahan bakar minyak di masa pemerintahan Presiden Susilo Bambang Yudhoyono.

Selain itu di tahun 2020 ini pemerintah melalui Badan Pusat Statistik akan menyelenggarakan Sensus Penduduk Tahun 2020. Tahapan dari Sensus penduduk ini telah dimulai dengan melaksanakan Sensus Penduduk Online dan kemudian dilanjutkan dengan pendataan dengan turun langsung ke lapangan (wawancara/Sensus Penduduk Offline). Untuk kegiatan Sensus Penduduk Online sendiri telah dilaksanakan pada tanggal 15 Februari 2020 


\section{Firman}

sebelum pasien pertama Covid-19 ditemukan di Indonesia. Karena wabah Covid-19, penutupan Sensus Penduduk Online pun diperpanjang dari tanggal 21 Maret 2020 menjadi tanggal 29 Mei 2020. Sedangkan tahapan Sensus Penduduk Offline pun harus mengalami penyesuaian menjadi tanggal 01 September hingga 30 September 2020 (BPS, 2020).

\subsection{TANTANGAN DALAM PENGUMPULAN DATA MASA PANDEMI COVID-19}

Pandemi Covid-19 yang menyebabkan perubahan di segala aspek kehidupan pada orang (individu), rumah tangga, dan masyarakat secara luas membuat kegiatan Official Statistics juga mengalami perubahan, terutama dalam hal pengumpulan data. Adanya pembatasan sosial yang terjadi di tengah masyarakat berupa larangan berkumpul/membuat keramaian menyebabkan sulitnya untuk melakukan kegiatan Official Statistics untuk pengumpulan data secara langsung ke lapangan. Metode konvensional yang selama ini dilakukan dengan turun ke lapangan untuk mendapatkan data ke sumber data, di masa pandemi juga akan mengalami kendalanya sendiri. Sebagian masyarakat akan mempunyai persepsi membatasi kegiatan bertatap muka dengan orang lain karena takut untuk tertular oleh virus Covid-19 ini. Jika hal ini yang terjadi, maka tahapan pengumpulan data juga akan mengalami kendala.

Kesulitan dalam pengumpulan data di lapangan, di masa pandemi Covid-19 di atasi melalui perangkat teknologi informasi yang ada. Komputer, aplikasi media sosial, dan adanya jaringan internet mampu untuk mengumpulkan data di lapangan dengan cepat dan hasil yang diharapkan juga bisa lebih baik. Pengumpulan data melalui kuesioner yang diisi secara online, dan pengumpulan data melalui telepon ke responden adalah cara yang paling sesuai di masa pandemi Covid-19 dibandingkan dengan cara biasa dengan bertatap muka langsung dengan responden. Hampir semua data yang didapat dalam rangka penelitian mengenai Covid-19 dilakukan menggunakan survei online dengan membuat pertanyaan-pertanyaan dalam suatu kuesioner. Hanya saja yang perlu menjadi perhatian adalah pemahaman dalam pengisian data oleh responden harus dipastikan sama dengan maksud data yang akan diisi untuk menghindari terjadinya kesalahan dalam pengisian form data.

\subsection{Peran Official Statistics di Masa Pandemi Covid-19}

Sejak kemunculan Covid-19 di Indonesia di awal Maret 2020 yang lalu, Pemerintah Indonesia dalam menyikapi pandemi global Covid-19 telah membentuk Gugus Tugas Penanganan Covid-19 yang sekarang telah berganti nama menjadi Satuan Tugas Covid-19 dan membuat web/laman resmi mengenai informasi seputar virus Covid-19 di Indonesia melalui laman www.covid19.go.id. Salah satu tugas dari gugus tugas ini adalah menyampaikan informasi mengenai perkembangan data penderita Covid-19 di Indonesia. Data tersebut diupdate secara harian dan disampaikan secara berkala melalui media massa. Tujuannya adalah untuk membantu masyarakat dalam mendapatkan informasi mengenai data Covid-19 dengan baik. Pencatatan data harian ini merupakan peran streategis yang dilakukan dari Official Statistic. Tidak saja data 


\section{Firman}

penderita yang dikumpulkan, tetapi seiring berjalannya waktu, data jumlah pasien yang sembuh, dan pasien yang meninggal karena Covid-19 ini pun menjadi variabel yang dicatat.

Pencatatan data mengenai Covid-19 juga dilakukan oleh seluruh negara yang warga negaranya mempunyai kasus terinfeksi Covid-19. Jika seluruh negara melakukan pencatatan yang sama tentang Covid-19 maka akan dihasilkan sebuah database penderita yang terinfeksi virus Covid-19. Saat ini berdasarkan data dari World Health Organization (WHO) Amerika Serikat merupakan negara dengan tingkat infeksi tertinggi di seluruh dunia (4.263.531 kasus) sedangkan negara-negara di kawasan pasifik mempunyai tingkat infeksi Covid-19 yang rendah.

Peran Official Statistics di masa pandemic Covid-19 sangat terasa dari kegiatan pendataan mengenai pandemi ini. Dari data yang telah terkumpul dapat memberikan informasi yang sesuai mengenai tingkat penyebaran virus Corona di suatu wilayah. Selain itu data yang diperoleh mengenai Covid-19 oleh para ahli dalam metode peramalan digunakan untuk mendapatkan model yang sesuai yang dapat melakukan estimasi/perkiraan berapa lama wabah Covid-19 ini terjadi dan kapan akan berakhir. Tentunya penggunaan metode-metode peramalan kontemporer dapat digunakan untuk masalah ini.

\section{KESIMPULAN}

Kegiatan pengumpulan data melalui Official Statistics mengalami transformasi selama pandemic Covid-19. Penggunaan metode online dalam pengumpulan data adalah cara yang paling sesuai di masa pandemi ini. Tanpa data yang baik mustahil untuk dapat menyelesaikan pandemi Covid-19 dengan tepat. Data Covid-19 yang tersedia lengkap dan up to date sangat membantu untuk pengambilan kebijakan dalam penanggulangan pandemi Covid-19. Diharapkan dengan pendataan yang baik dapat diambil kebijakan penanggulangan pandemi Covid-19 yang tepat pula.

\section{KONFLIK KEPENTINGAN}

Dengan ini saya selaku penulis paper menyatakan bahwa saya tidak terlibat konflik dengan pihak-pihak lain dalam hal pembuatan dan penerbitan paper

\section{REFERENSI}

[1] Badan Pusat Statistik., 2020. Sensus Penduduk Tahun 2020. www.bps.go.id/sp2020/.

[2] Estonia Statistics., 2013. What are official statistics and how are they produced?. www.stat.ee > what-are-official-statistics-and-how-are-t....

[3] Ljones Olav., 2020. Pandemic and official statistics; some comments on recent COVID-19 experiences. Statistical Journal of the IAOS, 36 (2020) 285-290.

[4] WHO., 2020. WHO Coronavirus Disease (COVID-19) Dashboard. https://covid19.who.int/ [30 Juli 2020]

[5] Sirusa BPS. Penjelasan Umum Statistik Dasar. https://sirusa.bps.go.id/sirusa/index.php/dasar/page?view=definisi 